\title{
Respons Fisiologis Ayam KUB (Kampung Unggul Balitbangtan) dan Ayam Walik dengan Haplotipe Gen HSP70 Berbeda yang Terpapar Cekaman Panas Akut
}

\section{(Physiological Response of KUB (Kampung Unggul Balitbangtan) and Walik Chickens with Different HSP70 Gene Haplotype Exposed to Acute Heat Stress)}

\author{
Any Aryani ${ }^{1}$, Dedy Duryadi Solihin ${ }^{2}$, Cece Sumantri ${ }^{3}$, Rudi Afnan ${ }^{3 \star}$, Tike Sartika ${ }^{4}$
}

(Diterima Februari 2020/Disetujui Maret 2021)

\begin{abstract}
ABSTRAK
Penelitian ini bertujuan mengukur respons fisiologis cekaman panas akut pada ayam Kampung Unggul Balitbangtan (KUB) dan ayam walik dengan empat haplotipe gen HSP70 berbeda (H1', H1, H2, dan H3). Cekaman panas akut diberikan pada suhu $35^{\circ} \mathrm{C}$ selama satu jam. Data dianalisis berdasarkan pengukuran suhu rektal, distribusi suhu permukaan tubuh (area kepala, leher, badan, dan kaki) dan kadar hormon (kortikosteron dan triiodotironin), serta waktu mulai panting. Suhu permukaan tubuh dideteksi dengan menggunakan termografi inframerah. Hasil penelitian menunjukkan bahwa ayam walik haplotipe $\mathrm{H} 1$ lebih rentan cekaman panas berdasarkan suhu rektal, sedangkan ayam walik haplotipe $\mathrm{H} 1$ ' lebih banyak melepaskan panas melalui permukaan tubuh di area kaki.
\end{abstract}

Kata kunci: ayam KUB, ayam walik, cekaman panas, hormon, termografi inframerah

\section{ABSTRACT}

This study was conducted to determine the physiological response of acute heat stress in Kampung Unggul Balitbangtan (KUB) and Walik chickens with four different HSP70 gene haplotypes (H1', H1, H2, and H3). Acute heat stress is carried out at $35^{\circ} \mathrm{C}$ for one hour. The data was analyzed based on rectal temperature measurements, distribution of body surface temperature (head, neck, body, and leg area), hormone levels (corticosterone and triiodothyronine), and time of panting. Body surface temperature is detected using infrared thermography. The results showed that haplotype $\mathrm{H} 1$ Walik chicken is more susceptible to heat stress based on the rectal temperature. In contrast, $\mathrm{H} 1$ ' haplotype Walik chicken released more heat through the body surface in the leg area.

Keywords: heat stress, hormone, KUB chicken, infrared thermography, walik chicken

\section{PENDAHULUAN}

Ayam merupakan hewan homeotermis (Romanoff 1941), dengan tubuh ditutupi bulu dan tidak memiliki kelenjar keringat. Suhu lingkungan yang tinggi dapat menyebabkan ayam mengalami cekaman panas. Cekaman panas yang intens (akut) atau cekaman panas yang berlangsung dalam waktu lama (kronis) dapat memengaruhi pertumbuhan, penurunan

1 Program Studi Biologi, Departemen Pendidikan Biologi, Fakultas Pendidikan Matematika dan IImu Pengetahuan Alam Universitas Pendidikan Indonesia, Jl. Dr. Setiabudi No.229, Bandung 40154

2 Departemen Biologi, Fakultas Matematika dan IImu Pengetahuan Alam Institut Pertanian Bogor, Kampus IPB Darmaga, Bogor 16680

${ }^{3}$ Departemen Ilmu Produksi dan Teknologi Peternakan, Fakultas Peternakan Institut Pertanian Bogor, Kampus IPB Darmaga, Bogor 16680

${ }^{4}$ Balai Penelitian Ternak. Jl. Veteran III, PO BOX 221 Ciawi, Bogor 16720

*Penulis Korespondensi: Email: rudi_afnan@apps.ipb.ac.id produksi telur, dan bahkan menyebabkan kematian ayam (Barrett et al. 2019).

Meningkatnya suhu lingkungan yang tinggi akan direspons ayam sebagai cekaman panas. Cekaman panas tersebut akan menyebabkan suhu rektal meningkat, dan ayam akan berusaha mempertahankan suhu tubuhnya dengan melepaskan panas melalui paruh (panting) dan permukaan tubuh. Penelitian tentang dampak suhu tinggi pada respons fisiologi (suhu rektal, suhu permukaan tubuh, dan panting) pada ayam kampung dan ayam ras menunjukkan bahwa ayam kampung lebih toleran terhadap suhu tinggi, sedangkan ayam ras lebih sensitif terhadap perubahan suhu (Komalasari 2014). Selain itu, deteksi hormon kortikosteron dan triiodotironin membuktikan bahwa kedua hormon tersebut dapat dijadikan sebagai indikator terjadinya cekaman panas pada ayam (Melesse et al. 2011; Soleimani et al. 2011).

Beberapa gen pada ayam diketahui berasosiasi dengan sifat ketahanan terhadap cekaman panas, di antaranya: gen naked-neck $(\mathrm{Na})$, gen frizzle $(\mathrm{F})$, dan 
gen dwarf (dw) (Lin et al. 2006). Di sisi lain, salah satu senyawa yang dihasilkan tubuh untuk mengatasi cekaman panas adalah heat shock protein 70 (HSP70). Gen HSP70 bekerja sebagai chaperone, bertugas mengatur pelipatan kembali (refolding) protein-protein secara benar sehingga dapat melindungi sel dari kerusakan akibat cekaman panas (Tkáčová \& Angelovičová 2012). Gen HSP70 dianggap sebagai penanda biologi ideal terhadap cekaman panas pada hewan ternak (Archana et al. 2017).

Asosiasi antara polimorfisme gen HSP70 dengan resistensi cekaman panas telah dijadikan sebagai penanda dalam proses seleksi untuk menghasilkan jenis ayam yang tahan terhadap suhu (Mazzi et al. 2003; Tamzil et al. 2013b; Liang et al. 2016). Namun, penelitian keragaman gen HSP70 dan respons fisiologis terhadap cekaman panas pada ayam lokal Indonesia masih sangat terbatas (Tamzil et al. 2013a, 2013b).

Tujuan penelitian ini adalah mengevaluasi respons fisiologis cekaman panas akut pada ayam Kampung Unggul Balitbangtan (KUB) dan ayam walik dengan haplotipe gen HSP70 berbeda $\left(\mathrm{H}^{\prime}{ }^{\prime}, \mathrm{H} 1, \mathrm{H} 2\right.$, dan $\left.\mathrm{H} 3\right)$ untuk menentukan haplotipe ayam yang tahan cekaman panas. Parameter yang diamati meliputi pengukuran suhu rektal, distribusi suhu permukaan tubuh (area kepala, leher, badan, dan kaki), dan konsentrasi hormon (kortikosteron dan triiodotironin), serta waktu mulai panting.

\section{METODE PENELITIAN}

\section{Seleksi Ayam}

Ayam KUB dan ayam walik yang digunakan dalam penelitian ini merupakan ayam yang telah diidentifikasi haplotipe-nya berdasarkan keragaman gen HSP70 (Aryani et al. 2019). Keragaman gen HSP70 pada ayam KUB, ayam walik, dan ayam kate walik menunjukkan dua haplotipe di daerah 5'UTR, dan empat haplotipe di daerah penyandi protein. Kedua kelompok haplotipe tersebut diidentifikasi berdasarkan tiga situs spesifik, yaitu g.44A>G (daerah 5'UTR), g.370A $>\mathrm{G}$, dan g.388C $>\mathrm{G}$ (daerah penyandi protein). Analisis lebih lanjut pada haplotipe 2 di daerah 5'UTR dengan haplotipe $1(\mathrm{H} 1)$ di daerah penyandi protein memperlihatkan kesamaan nukleotida di situs g. $370 A>G$ dan g.388C $>G$, sebaliknya perbedaan antara kedua haplotipe tersebut hanya terdapat pada situs g.44A $>$ G. Oleh sebab itu pada analisis berikutnya didapatkan haplotipe baru dan diberi nama haplotipe H1' (Tabel 1). Selanjutnya, empat haplotipe di daerah penyandi protein gen $\mathrm{HSP} 70(\mathrm{H} 1, \mathrm{H} 2, \mathrm{H} 3$, dan $\mathrm{H} 4)$ memiliki ragam basa nukleotida yang berbeda pada situs g. $370 A>G$ dan g. $388 C>G$, tetapi memiliki basa nukleotida yang sama pada situs g.44A $>G$ (Tabel 1).

Penelitian sebelumnya (Aryani et al. 2019) menunjukkan distribusi haplotipe gen HSP70 sangat beragam pada setiap rumpun dan jenis kelamin ayam (Tabel 2). Distribusi haplotipe ayam KUB betina dan jantan hanya terdapat pada empat haplotipe, yaitu: $\mathrm{H} 1{ }^{\prime}$ $(n=1$ o dan $n=1 \hat{\jmath}), \mathrm{H} 1(n=4$ o , dan $n=1$ ठ $), \mathrm{H} 2(n$ $=15$ dan $\left.n=12 \delta^{\lambda}\right)$, dan $\mathrm{H} 3\left(n=10+\right.$ dan $\left.n=6{ }^{\lambda}\right)$. Lain halnya dengan distribusi haplotipe pada ayam walik betina dan jantan yang mencakup lima haplotipe:

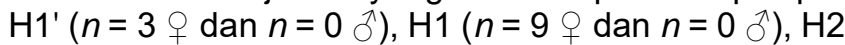

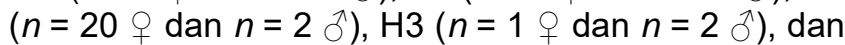
$\mathrm{H} 4(n=4$ o dan $n=0$ गे). Sebaliknya pada ayam kate walik hanya ditemukan satu haplotipe, yakni $\mathrm{H} 2(n=2$ q dan $n=1$ ऊ).

Sampel untuk uji tantang dicuplik secara purposif dengan menggunakan sebaran haplotipe yang sama (equal) pada rumpun ayam KUB dan ayam walik. Haplotipe yang terpilih ada empat, yaitu H1', H1, H2, dan H3. Oleh sebab itu, dalam penelitian ini hanya digunakan sebanyak empat ekor ayam betina dewasa dari setiap rumpun ayam, mewakili setiap haplotipe gen HSP70 pada tahap uji tantang cekaman panas.

\section{Uji Tantang dan Respons Fisiologis Cekaman Panas}

Sebanyak empat ekor ayam betina dewasa masingmasing dari ayam KUB dan ayam walik dengan haplotipe berbeda $\left(\mathrm{H} 11^{\prime}, \mathrm{H} 1, \mathrm{H} 2\right.$, dan $\left.\mathrm{H} 3\right)$ selanjutnya diuji tantang untuk mengukur respons fisiologis terhadap cekaman panas akut pada suhu $35^{\circ} \mathrm{C}$ selama satu jam dengan menggunakan heat chamber. Heat chamber dibuat berbentuk kotak dengan ukuran panjang $\times$ lebar $\times$ tinggi $=60 \mathrm{~cm} \times 60 \mathrm{~cm} \times 60 \mathrm{~cm}$ menggunakan papan kayu lapis dan akrilik. Heat chamber ini dilengkapi dengan pemanas, termostat, dan termometer digital, serta ventilasi udara dan kipas.

Tabel 1 Haplotipe gen HSP70 pada ayam KUB dan walik berdasarkan tiga single nucleotide polymorphism (SNP) di posisi g.44A>G (daerah 5'UTR), g.370A $>G$, dan g.388C $>G$ (daerah penyandi protein)

\begin{tabular}{lccc}
\hline Haplotipe & $\begin{array}{c}\text { Daerah } \\
\text { 5'UTR }\end{array}$ & \multicolumn{2}{c}{ Daerah penyandi protein } \\
\cline { 2 - 4 } & g.44A $>\mathrm{G}$ & g.370A $>\mathrm{G}$ & g.388C $>\mathrm{G}$ \\
\hline $\mathrm{H} 1{ }^{\prime}$ & $\mathrm{G}$ & $\mathrm{A}$ & $\mathrm{C}$ \\
$\mathrm{H} 1$ & $\mathrm{~A}$ & $\mathrm{~A}$ & $\mathrm{C}$ \\
$\mathrm{H} 2$ & $\mathrm{~A}$ & $\mathrm{~A}$ & $\mathrm{G}$ \\
$\mathrm{H} 3$ & $\mathrm{~A}$ & $\mathrm{G}$ & $\mathrm{C}$ \\
$\mathrm{H} 4$ & $\mathrm{~A}$ & $\mathrm{G}$ & $\mathrm{G}$ \\
\hline
\end{tabular}

Tabel 2 Distribusi haplotipe gen HSP70 pada ayam KUB, ayam walik, dan ayam kate walik

\begin{tabular}{|c|c|c|c|c|c|c|}
\hline \multirow{2}{*}{ Rumpun } & \multicolumn{5}{|c|}{ Haplotipe Gen HSP70 } & \multirow{2}{*}{ Jumlah } \\
\hline & $\mathrm{H} 1^{\prime}$ & $\mathrm{H} 1$ & $\mathrm{H} 2$ & $\mathrm{H} 3$ & $\mathrm{H} 4$ & \\
\hline \multicolumn{7}{|l|}{ Ayam KUB } \\
\hline - Betina & 1 & 4 & 15 & 10 & - & 30 \\
\hline - Jantan & 1 & 1 & 12 & 6 & - & 20 \\
\hline Ayam walik & & & & & & \\
\hline - Betina & 3 & 9 & 20 & 1 & 4 & 37 \\
\hline $\begin{array}{l}\text { - Jantan } \\
\text { Ayam kate walik }\end{array}$ & - & - & 2 & 2 & - & 4 \\
\hline - Betina & - & - & 2 & - & - & 2 \\
\hline - Jantan & - & - & 1 & - & - & 1 \\
\hline
\end{tabular}


Uji tantang ini diulang tiga kali pada waktu yang berbeda, dengan selang waktu satu hari pada jenis ayam yang sama.

Respons fisiologis terhadap cekaman panas dianalisis berdasarkan hasil pengukuran suhu rektal dengan termometer digital (Omron MC-341); suhu permukaan tubuh dengan termografi inframerah (thermal imaging: thermovission FLIR A330); dan pengukuran konsentrasi hormon korticosteron dan triiodotironin dengan metode enzyme-linked immunosorbent assay (ELISA) menggunakan Chicken Corticosterone, Cort (Fine Test cat\# ECH0077, dan Chicken Triiodothyronine T3 (Fine Test, cat\# $\mathrm{ECH0109).} \mathrm{Analisis} \mathrm{hormone} \mathrm{tersebut} \mathrm{dilakukan} \mathrm{di}$ Laboratorium Mikrobiologi dan Imunologi, Pusat Studi Satwa Primata, Institut Pertanian Bogor.

\section{Analisis Data}

Waktu mulai panting diukur pada saat cekaman panas, sedangkan suhu rektal, suhu permukaan tubuh (area kepala, leher, badan, dan kaki), dan konsentrasi hormon triiodotironin dan kortikosteron diukur sebelum dan sesudah cekaman panas. Data suhu rektal, suhu permukaan tubuh, dan konsentrasi hormon dianalisis berdasarkan delta $(\Delta)$ atau perubahan pengukuran sesudah dan sebelum cekaman panas pada setiap haplotipe $(\mathrm{H} 1$ ', $\mathrm{H} 1, \mathrm{H} 2$, dan $\mathrm{H} 3)$ berdasarkan rumpun ayam (ayam KUB dan ayam walik) dengan menggunakan ANOVA (analysis of variance) satu arah.

\section{HASIL DAN PEMBAHASAN}

\section{Panting}

Waktu mulai panting (Tabel 3) tidak menunjukkan perbedaan signifikan $(P>0,05)$ pada setiap haplotipe dalam rumpun ayam KUB dan ayam walik. Waktu mulai panting (detik) dalam penelitian ini diukur pada saat cekaman panas, dan memperlihatkan bahwa kisaran waktu panting ayam KUB dan ayam walik pada haplotipe yang sama $\left(\mathrm{H} 11^{\prime}, \mathrm{H} 1, \mathrm{H} 2\right.$, dan $\left.\mathrm{H} 3\right)$ yang tidak berbeda. Waktu panting terendah ditunjukkan oleh ayam berhaplotipe $\mathrm{H} 3$, sebaliknya waktu panting tertinggi diperlihatkan oleh ayam berhaplotipe $\mathrm{H} 1$ '. Waktu panting yang tinggi mengindikasikan bahwa haplotipe ayam tersebut lebih toleran terhadap cekaman panas. Walaupun demikian, berdasarkan analisis delta cekaman panas, waktu mulai panting pada setiap haplotipe ayam KUB dan ayam walik ternyata tidak menunjukkan perbedaan signifikan ( $P$ $>0,05$ ). Hasil penelitian lain menunjukkan ayam ras petelur memulai panting lebih cepat daripada ayam kampung (Tamzil et al. 2013b, Komalasari 2014). Lebih lanjut ditemukan bahwa genotipe gen HSP70 yang paling cepat mengalami panting adalah genotipe DD pada ayam ras, sedangkan yang paling lambat adalah genotipe $A D$ pada ayam kampung (Tamzil et al. 2013b).
Suhu lingkungan yang tinggi akan menyebabkan tertimbunnya panas dalam tubuh sehingga ayam akan tercekam panas. Pada saat suhu lingkungan tinggi, kestabilan suhu tubuh dipertahankan dengan menyeimbangankan antara produksi panas dengan pelepasan panas. Berbagai cara untuk mengurangi beban panas tersebut, di antaranya dengan radiasi, konduksi, dan konveksi (sensible heat loss) melalui permukaan tubuh. Apabila radiasi, konduksi, dan konveksi tidak mampu mengatasi cekaman panas, maka mekanisme yang bekerja adalah evaporasi (insensible heat loss). Panting merupakan mekanisme utama pelepasan panas secara evaporasi melalui saluran napas pada saat suhu lingkungan meningkat. Saat terjadi panting, ayam terlihat bernapas pendek (tersengal-sengal) sambil membuka paruhnya. Frekuensi panting bertambah seiring dengan meningkatnya suhu lingkungan. Pada saat panting, laju napas meningkat hingga 200x per menit (Cunningham \& Klein 2007). Peningkatan laju respirasi akan meningkatkan pelepasan $\mathrm{CO}_{2}$ dalam jumlah besar sehingga $\mathrm{pH}$ darah meningkat dan terjadi respirasi alkalosis. Ayam broiler yang diberi cekaman panas pada $33 \pm 1^{\circ} \mathrm{C}$ selama empat jam per hari dalam kurun waktu 14 hari menunjukkan mulai panting ketika suhu lingkungan mencapai $30,0-31,5^{\circ} \mathrm{C}$ (Sugito \& Delima 2009).

\section{Suhu Rektal}

Suhu rektal untuk setiap haplotipe (Tabel 4) menunjukkan bahwa suhu rektal ayam KUB dan ayam walik pada saat sebelum dan sesudah cekaman panas masih dalam kisaran suhu normal, yaitu 41 hingga $42^{\circ} \mathrm{C}$ (Wilson 1948). Analisis delta suhu rektal pada haplotipe ayam KUB tidak menunjukkan perbedaan yang signifikan $(P>0,05)$, sebaliknya pada ayam walik perbedaannya signifikan. Suhu rektal pada setiap haplotipe ayam KUB dan ayam walik meningkat setelah terpapar cekaman panas, kecuali pada ayam KUB haplotipe $\mathrm{H}^{\prime}$ '. Analisis lebih lanjut (delta cekaman panas) pada ayam walik dengan haplotipe $\mathrm{H} 1$

Tabel 3 Waktu mulai panting pada setiap haplotipe rumpun ayam

\begin{tabular}{lc}
\hline Haplotipe rumpun ayam & Waktu mulai panting (detik) \\
\hline Ayam KUB H1' & $200 \pm 91,65$ \\
Ayam KUB H1 & $120 \pm 60,00$ \\
Ayam KUB H2 & $140 \pm 151,00$ \\
Ayam KUB H3 & $60 \pm 60,00$ \\
Nilai F & 1,042 \\
Nilai P & 0,425 \\
& \\
Ayam walik H1' & $180 \pm 103,92$ \\
Ayam walik H1 & $160 \pm 151,00$ \\
Ayam walik H2 & $140 \pm 34,64$ \\
Ayam walik H3 & $80 \pm 34,64$ \\
Nilai F & 0,622 \\
Nilai P & 0,620 \\
\hline
\end{tabular}


Tabel 4 Suhu rektal pada setiap haplotipe rumpun ayam

\begin{tabular}{|c|c|c|c|}
\hline \multirow{2}{*}{ Haplotipe rumpun ayam } & \multicolumn{3}{|c|}{ Suhu rektal $\left({ }^{\circ} \mathrm{C}\right)$} \\
\hline & Sebelum cekaman & Sesudah cekaman & Delta \\
\hline Ayam KUB H1' & $41,70 \pm 0,26$ & $41,47 \pm 0,31$ & $-0,23 \pm 0,06 a$ \\
\hline Ayam KUB H1 & $41,30 \pm 0,40$ & $41,37 \pm 0,21$ & $0,07 \pm 0,21 a$ \\
\hline Ayam KUB H2 & $41,60 \pm 0,30$ & $41,83 \pm 0,21$ & $0,23 \pm 0,12 a$ \\
\hline Ayam KUB H3 & $41,47 \pm 0,31$ & $41,70 \pm 0,20$ & $0,23 \pm 0,31 a$ \\
\hline Nilai $F$ & & & 3,790 \\
\hline Nilai $P$ & & & 0,059 \\
\hline Ayam walik $\mathrm{H} 1{ }^{\prime}$ & $41,07 \pm 0,21$ & $41,43 \pm 0,12$ & $0,37 \pm 0,21 a$ \\
\hline Ayam walik $\mathrm{H} 1$ & $40,87 \pm 0,15$ & $41,93 \pm 0,06$ & $1,07 \pm 0,15 b$ \\
\hline Ayam walik $\mathrm{H} 2$ & $41,17 \pm 0,06$ & $41,73 \pm 0,25$ & $0,57 \pm 0,25 a$ \\
\hline Ayam walik H3 & $41,03 \pm 0,15$ & $41,63 \pm 0,06$ & $0,60 \pm 0,10 a$ \\
\hline Nilai F & & & 7,524 \\
\hline Nilai $P$ & & & $0,010^{*}$ \\
\hline
\end{tabular}

menggambarkan peningkatan suhu rektal yang berbeda signifikan. Hal ini mengindikasikan bahwa ayam walik haplotipe $\mathrm{H} 1$ lebih cepat merespons atau lebih rentan terhadap cekaman panas dibandingkan dengan haplotipe ayam lainnya $\left(\mathrm{H} 1{ }^{\prime}, \mathrm{H} 2\right.$, dan $\left.\mathrm{H} 3\right)$. Peneliti lain mengemukakan suhu rektal ayam hutan merah berkisar pada suhu 41 hingga $42^{\circ} \mathrm{C}$ (Soleimani et al. 2011). Di sisi lain, cekaman panas dapat meningkatkan suhu rektal pada ayam kampung dan ayam arab yang tercekam panas pada suhu $40^{\circ} \mathrm{C}$ selama $0,5,1$, dan $1,5 \mathrm{jam}$. Suhu rektal normal $41,18 \pm$ $0,27^{\circ} \mathrm{C}$ meningkat menjadi $43,30 \pm 0,12^{\circ} \mathrm{C}$ (ayam kampung) dan $41,17 \pm 0,25^{\circ} \mathrm{C}$ naik menjadi $43,28 \pm$ $0,13^{\circ} \mathrm{C}$ (ayam arab); sedangkan suhu rektal ayam ras adalah $43,71^{\circ} \mathrm{C}$ (Tamzil et al. 2013b).

Suhu rektal mencerminkan suhu tubuh ayam. Suhu rektal merupakan manifestasi dalam upaya mencapai keseimbangan antara panas yang diproduksi dengan panas yang dikeluarkan. Perubahan suhu rektal merupakan salah satu pengaruh dari mekanisme termoregulasi yang dilakukan dalam rangka mempertahankan suhu tubuhnya. Umumnya suhu tubuh ayam dewasa berkisar antara 41,11 dan $41,67^{\circ} \mathrm{C}$ (Wilson 1948). Kemampuan adaptasi ayam dengan panas juga sangat memengaruhi respons fisiologisnya. Suhu tinggi dengan kelembapan tinggi lebih mengganggu dibandingkan dengan suhu tinggi dengan kelembapan rendah (Ajakaiye et al. 2011). Pada ayam petelur, suhu normal beragam, dipengaruhi oleh umur, kelamin, lingkungan, panjang waktu siang dan malam, serta makanan yang dikonsumsi (Lamoreux \& Hutt 1939). Oleh sebab itu, suhu rektal dapat digunakan sebagai indikator ayam tahan cekaman panas (Chen et al. 2013).

\section{Suhu Permukaan Tubuh}

Suhu permukaan tubuh (area kepala, leher, badan, dan kaki) pada setiap haplotipe berdasarkan rumpun ayam KUB dan ayam walik disajikan berturut-turut pada Tabel 5 hingga Tabel 8. Diinformasikan bahwa pelepasan panas pada setiap haplotipe ayam KUB tidak berbeda signifikan $(P>0,05)$. Sebaliknya pada ayam walik haplotipe $\mathrm{H} 1$ ', suhu di area kaki menunjukkan perbedaan signifikan. Temuan ini sesuai dengan kesimpulan Nääs et al. (2010) dan Nascimento et al. (2011). Suhu permukaan tubuh yang minim bulu dan berbulu pada ayam broiler diukur dengan menggunakan termografi inframerah (Nääs et al. 2010). Dinyatakan bahwa area tubuh ayam yang minim bulu atau featherless (jengger, mata, telinga, pial, palang sayap, dan kaki) memiliki suhu yang lebih tinggi dibandingkan dengan area tubuh ayam yang tertutupi bulu (kepala, leher, punggung, sayap terbang, dada, paha, bagian bawah, dan ekor). Suhu permukaan di bagian sayap, kepala, punggung, dan jengger ayam broiler juga meningkat seiring dengan meningkatnya suhu lingkungan. Peningkatan suhu terbesar terdapat di area kaki $\left(14,8^{\circ} \mathrm{C}\right)$ dengan suhu lingkungan beragam: 18, 25, dan $32^{\circ} \mathrm{C}$ (Nascimento et al. 2011). Dengan demikian, daerah yang minim bulu lebih menguntungkan bagi unggas terutama dalam hal membuang kelebihan panas tubuh dan meningkatkan ketahanan terhadap cekaman panas (Yalçin et al. 1997, Gerken et al. 2006).

Data penelitian ini mengungkap suhu permukaan tubuh ayam (area kepala, leher, badan, dan kaki) lebih rendah dibandingkan dengan suhu rektal. Dapat dijelaskan karena suhu permukaan tubuh berhubungan langsung dengan lingkungan. Pengukuran suhu permukaan tubuh menggunakan thermovision FLIR A330 meliputi bagian tubuh yang umumnya ditutupi bulu (area leher dan area badan) dan bagian tanpa bulu (area kepala dan area kaki), sesaat sebelum dan sesudah ayam terpapar cekaman panas. Perlakuan cekaman panas dengan menggunakan chamber climate adalah pada suhu $35^{\circ} \mathrm{C}$ selama satu jam, dengan kelembapan menyesuaikan suhu yang ditetapkan $\left(35^{\circ} \mathrm{C}\right)$. Suhu yang tercatat selama cekaman panas berkisar antara $35,3 \pm 0,2^{\circ} \mathrm{C}$ dan 35,4 $\pm 0,2^{\circ} \mathrm{C}$; dengan kelembapan $55,4 \pm 2,9 \%$ sampai 60,5 $\pm 1,1 \%$.

Pencitraan termal (thermal imaging) merupakan teknik pengukuran suhu permukaan suatu objek tanpa kontak langsung dengan objeknya. Termografi inframerah secara luas telah digunakan di antaranya untuk menggambarkan penutupan bulu pada ayam petelur 
Tabel 5 Suhu permukaan tubuh area kepala pada setiap haplotipe rumpun ayam

\begin{tabular}{lccc}
\hline \multirow{2}{*}{ Haplotipe rumpun ayam } & \multicolumn{3}{c}{ Suhu area kepala $\left({ }^{\circ} \mathrm{C}\right)$} \\
\cline { 2 - 4 } & Sebelum cekaman & Sesudah cekaman & Delta \\
\hline Ayam KUB H1' & $35,80 \pm 0,10$ & $36,07 \pm 0,25$ & $0,27 \pm 0,35 \mathrm{a}$ \\
Ayam KUB H1 & $36,27 \pm 0,55$ & $36,57 \pm 0,50$ & $0,30 \pm 0,10 \mathrm{a}$ \\
Ayam KUB H2 & $35,87 \pm 0,86$ & $35,33 \pm 1,10$ & $-0,53 \pm 0,42 \mathrm{a}$ \\
Ayam KUB H3 & $36,17 \pm 0,50$ & $36,13 \pm 0,12$ & $-0,03 \pm 0,61 \mathrm{a}$ \\
Nilai F & & & 2,627 \\
Nilai P & & & 1,220 \\
& & $34,27 \pm 0,23$ & $0,97 \pm 1,00 \mathrm{a}$ \\
Ayam walik H1 & $33,30 \pm 0,82$ & $35,80 \pm 0,87$ & $0,43 \pm 1,30 \mathrm{a}$ \\
Ayam walik H1 & $35,37 \pm 0,58$ & $35,90 \pm 1,54$ & $0,33 \pm 1,10 \mathrm{a}$ \\
Ayam walik H2 & $35,57 \pm 0,49$ & $37,13 \pm 0,64$ & $1,53 \pm 1,25 \mathrm{a}$ \\
Ayam walik H3 & $35,60 \pm 0,61$ & & 0,670 \\
Nilai F & & & 0,594 \\
\hline
\end{tabular}

Tabel 6 Suhu permukaan tubuh area leher pada setiap haplotipe rumpun ayam

\begin{tabular}{lccc}
\hline \multirow{2}{*}{ Haplotipe rumpun ayam } & \multicolumn{3}{c}{ Suhu area leher $\left({ }^{\circ} \mathrm{C}\right)$} \\
\cline { 2 - 4 } & Sebelum cekaman & Sesudah cekaman & Delta \\
\hline Ayam KUB H1' & $33,33 \pm 0,25$ & $34,00 \pm 0,61$ & $0,67 \pm 0,70 \mathrm{a}$ \\
Ayam KUB H1 & $33,17 \pm 0,25$ & $33,60 \pm 0,26$ & $0,43 \pm 0,38 \mathrm{a}$ \\
Ayam KUB H2 & $32,60 \pm 1,68$ & $33,10 \pm 1,50$ & $0,50 \pm 0,53 \mathrm{a}$ \\
Ayam KUB H3 & $33,90 \pm 1,14$ & $33,27 \pm 0,38$ & $-0,63 \pm 1,00 \mathrm{a}$ \\
Nilai F & & & 0,187 \\
Nilai P & & & \\
& & $33,63 \pm 0,55$ & $1,97 \pm 0,15 \mathrm{a}$ \\
Ayam walik H1 & $31,67 \pm 0,61$ & $34,57 \pm 0,35$ & $0,87 \pm 0,83 \mathrm{a}$ \\
Ayam walik H1 & $33,70 \pm 0,52$ & $35,13 \pm 1,42$ & $0,37 \pm 1,46 \mathrm{a}$ \\
Ayam walik H2 & $34,77 \pm 0,35$ & $36,93 \pm 1,25$ & $2,10 \pm 1,40 \mathrm{a}$ \\
Ayam walik H3 & $34,83 \pm 0,15$ & & 1,784 \\
Nilai F & & & 0,228 \\
Nilai P & & & \\
\hline
\end{tabular}

Tabel 7 Suhu permukaan tubuh area badan pada setiap haplotipe rumpun ayam

\begin{tabular}{lccc}
\hline \multirow{2}{*}{ Haplotipe rumpun ayam } & \multicolumn{3}{c}{ Suhu area badan $\left({ }^{\circ} \mathrm{C}\right)$} \\
\cline { 2 - 4 } & Sebelum cekaman & Sesudah cekaman & Delta \\
\hline Ayam KUB H1' & $31,50 \pm 0,10$ & $32,80 \pm 1,01$ & $0,97 \pm 0,11 \mathrm{a}$ \\
Ayam KUB H1 & $32,33 \pm 0,25$ & $33,30 \pm 0,10$ & $-0,20 \pm 1,28 \mathrm{a}$ \\
Ayam KUB H2 & $32,27 \pm 1,57$ & $32,07 \pm 1,33$ & $-0,10 \pm 1,23 \mathrm{a}$ \\
Ayam KUB H3 & $31,97 \pm 1,24$ & $31,87 \pm 0,15$ & 1,523 \\
Nilai F & & & 0,281 \\
Nilai P & & & $0,80 \pm 0,70 \mathrm{a}$ \\
Ayam walik H1' & $31,30 \pm 0,62$ & $32,10 \pm 1,11$ & $0,27 \pm 0,40 \mathrm{a}$ \\
Ayam walik H1 & $33,47 \pm 0,32$ & $33,73 \pm 0,42$ & $0,63 \pm 1,03 \mathrm{a}$ \\
Ayam walik H2 & $34,00 \pm 0,26$ & $34,63 \pm 1,16$ & $-0,60 \pm 1,01 \mathrm{a}$ \\
Ayam walik H3 & $34,43 \pm 0,40$ & $33,83 \pm 0,64$ & 1,710 \\
Nilai F & & & 0,242 \\
Nilai P & & & \\
\hline
\end{tabular}

(Zhao et al. 2013), dan fisiologi termal hewan karena cekaman panas dan penyakit (McCafferty 2013). Peneliti lain menunjukkan bahwa ayam kampung lebih toleran terhadap suhu tinggi dibandingkan dengan ayam ras, di antaranya berdasarkan hasil pengukuran suhu permukaan tubuh (jengger, pial, dan kaki, serta bulu punggung) (Komalasari 2014).

\section{Konsentrasi Hormon}

Konsentrasi hormon triiodotironin dan kortikosteron pada setiap haplotipe berdasarkan rumpun ayam disajikan pada Tabel 9 dan Tabel 10. Sebelum dan sesudah cekaman panas, konsentrasi kedua hormon tersebut pada setiap haplotipe ayam KUB dan ayam walik sangat beragam tetapi delta suhu cekaman panas tidak menunjukkan perbedaan signifikan ( $P$ $>0,05)$ baik pada haplotipe ayam KUB maupun ayam walik. Hingga saat ini belum ada referensi yang menyebutkan besarnya konsentrasi kedua hormon itu pada ayam KUB atau ayam walik. Penelitian konsentrasi triiodotironin dan kortikosteron hormon dalam serum ayam broiler jantan yang dipelihara pada tiga suhu berbeda: $13-16^{\circ} \mathrm{C}$ (suhu rendah), $24-27^{\circ} \mathrm{C}$ (suhu sedang), dan $42-45^{\circ} \mathrm{C}$ (suhu tinggi) memberikan 
Tabel 8 Suhu permukaan tubuh area kaki pada setiap haplotipe rumpun ayam

\begin{tabular}{|c|c|c|c|}
\hline \multirow{2}{*}{ Haplotipe rumpun ayam } & \multicolumn{3}{|c|}{ Suhu area kaki $\left({ }^{\circ} \mathrm{C}\right)$} \\
\hline & Sebelum cekaman & Sesudah cekaman & Delta \\
\hline Ayam KUB H1' & $34,83 \pm 0,12$ & $35,33 \pm 0,85$ & $0,50 \pm 0,95 a$ \\
\hline Ayam KUB H1 & $35,50 \pm 0,56$ & $35,83 \pm 0,67$ & $0,33 \pm 1,21 a$ \\
\hline Ayam KUB H2 & $35,37 \pm 0,59$ & $35,33 \pm 0,78$ & $-0,03 \pm 0,93 a$ \\
\hline Ayam KUB H3 & $35,83 \pm 0,70$ & $36,03 \pm 0,29$ & $0,20 \pm 0,46 a$ \\
\hline Nilai $F$ & & & 0,177 \\
\hline Nilai $P$ & & & 0,909 \\
\hline Ayam walik $\mathrm{H} 1$ ' & $32,57 \pm 0,55$ & $34,03 \pm 0,55$ & $1,47 \pm 0,21 b$ \\
\hline Ayam walik H1 & $33,80 \pm 0,36$ & $34,70 \pm 0,50$ & $0,90 \pm 0,69 a$ \\
\hline Ayam walik $\mathrm{H} 2$ & $35,47 \pm 0,25$ & $35,07 \pm 0,67$ & $-0,40 \pm 0,44 a$ \\
\hline Ayam walik H3 & $35,53 \pm 1,07$ & $35,40 \pm 0,30$ & $-0,13 \pm 1,12 a$ \\
\hline Nilai $F$ & & & 4,651 \\
\hline Nilai $P$ & & & $0,036^{*}$ \\
\hline
\end{tabular}

Tabel 9 Konsentrasi hormon triiodotironin pada setiap haplotipe rumpun ayam

\begin{tabular}{lccc}
\hline \multirow{2}{*}{ Haplotipe rumpun ayam } & \multicolumn{3}{c}{ Konsentrasi triiodotironin $(\mathrm{ng} / \mathrm{mL})$} \\
\cline { 2 - 4 } & Sebelum cekaman & Sesudah cekaman & Delta \\
\hline Ayam KUB H1' & $3,96 \pm 0,75$ & $3,69 \pm 1,20$ & $-0,27 \pm 0,47 \mathrm{a}$ \\
Ayam KUB H1 & $2,21 \pm 1,33$ & $2,52 \pm 1,59$ & $0,31 \pm 2,42 \mathrm{a}$ \\
Ayam KUB H2 & $2,29 \pm 1,00$ & $3,35 \pm 1,02$ & $1,06 \pm 0,53 \mathrm{a}$ \\
Ayam KUB H3 & $4,97 \pm 2,63$ & $5,03 \pm 1,99$ & $0,06 \pm 2,03 \mathrm{a}$ \\
Nilai F & & & 0,368 \\
Nilai P & & & 0,778 \\
& & & $-2,68 \pm 2,63 \mathrm{a}$ \\
Ayam walik H1' & $6,03 \pm 2,15$ & $3,35 \pm 2,51$ & $-0,20 \pm 15,87 \mathrm{a}$ \\
Ayam walik H1 & $17,91 \pm 10,17$ & $17,71 \pm 6,94$ & $2,27 \pm 5,91 \mathrm{a}$ \\
Ayam walik H2 & $6,75 \pm 2,23$ & $15,02 \pm 6,63$ & $5,98 \pm 9,18 \mathrm{a}$ \\
Ayam walik H3 & $9,10 \pm 3,01$ & & 0,433 \\
Nilai F & & & 0,735 \\
Nilai P & & & \\
\hline
\end{tabular}

Tabel 10 Konsentrasi hormon kortikosteron pada setiap haplotipe rumpun ayam

\begin{tabular}{lccc}
\hline \multirow{2}{*}{ Haplotipe rumpun ayam } & \multicolumn{3}{c}{ Konsentrasi kortikosteron $(\mathrm{ng} / \mathrm{mL})$} \\
\cline { 2 - 4 } & Sebelum cekaman & Sesudah cekaman & Delta \\
\hline Ayam KUB H1' & $42,26 \pm 6,53$ & $28,27 \pm 13,45$ & $-13,98 \pm 15,67 \mathrm{a}$ \\
Ayam KUB H1 & $35,62 \pm 4,41$ & $33,76 \pm 5,67$ & $-1,86 \pm 9,25 \mathrm{a}$ \\
Ayam KUB H2 & $30,96 \pm 12,42$ & $39,80 \pm 15,88$ & $8,84 \pm 3,49 \mathrm{a}$ \\
Ayam KUB H3 & $49,83 \pm 21,68$ & $48,66 \pm 7,91$ & $-1,17 \pm 24,91 \mathrm{a}$ \\
Nilai F & & & 1,087 \\
Nilai P & & & 0,408 \\
& & & $3,19 \pm 66,33 \mathrm{a}$ \\
Ayam walik H1 & $64,42 \pm 35,22$ & $67,60 \pm 34,20$ & $-4,37 \pm 19,70 \mathrm{a}$ \\
Ayam walik H1 & $96,81 \pm 41,82$ & $92,44 \pm 27,95$ & $-11,46 \pm 18,45 \mathrm{a}$ \\
Ayam walik H2 & $64,67 \pm 43,16$ & $53,21 \pm 31,09$ & $-10,73 \pm 6,56 \mathrm{a}$ \\
Ayam walik H3 & $73,04 \pm 30,18$ & $62,31 \pm 31,69$ & 0,108 \\
Nilai F & & & 0,953 \\
Nilai P & & & \\
\hline
\end{tabular}

perbedaan signifikan (Kataria et al. 2008). Konsentrasi kortikosteron pada ayam broiler jantan yang dipelihara dengan suhu sedang $(7,3 \pm 0,54 \mathrm{ng} / \mathrm{mL})$ meningkat pada suhu tinggi $(13,1 \pm 0,78 \mathrm{ng} / \mathrm{mL})$. Sebaliknya, konsentrasi triiodotironin pada suhu sedang $(2,2 \pm 0,2$ $\mathrm{ng} / \mathrm{mL})$ menurun pada suhu tinggi $(1,4 \pm 0,3 \mathrm{ng} / \mathrm{mL})$ (Kataria et al. 2008). Peneliti lain mengungkap bahwa konsentrasi kortikosteron dalam plasma ayam hutan merah lebih tinggi dibandingkan dengan ayam kampung dan ayam broiler, walaupun konsentrasi kortikosteron pada ayam hutan merah tidak signifikan setelah cekaman panas $\left(36 \pm 1^{\circ} \mathrm{C}\right.$ selama tiga jam) (Soleimani et al. 2011). Pada ayam kampung dan ayam arab, konsentrasi kortikosteron meningkat setelah cekaman panas, yaitu 1,30 $\pm 0,58 \mu \mathrm{g} / \mathrm{dL}$ menjadi 4,62 $\pm 0,26 \mu \mathrm{g} / \mathrm{dL}$ (ayam kampung), dan 1,68 $\pm 0,53 \mu \mathrm{g} / \mathrm{dL}$ menjadi 5,11 $\pm 0,26 \mu \mathrm{g} / \mathrm{dL}$ (ayam arab) (Tamzil et al. 2013b). Lebih lanjut diketahui bahwa konsentrasi kortikosteron pada ayam broiler di Nepal tidak dipengaruhi oleh musim tetapi oleh zona iklim. Konsentrasi tertinggi kortikosteron terdapat di daerah tropis, diikuti daerah sedang dan terendah di daerah 
subtropis. Kombinasi musim dan zona iklim menunjukkan fenomena berikut: saat musim panas di daerah tropis, konsentrasi kortikosteron tertinggi, sebaliknya saat musim dingin di daerah subtropis, konsentrasinya terendah (Osti et al. 2017). Konsentrasi triiodotironin menurun signifikan dari $3,72 \pm 0,14$ $\mathrm{nmol} / \mathrm{L}$ menjadi $3,01 \pm 0,14 \mathrm{nmol} / \mathrm{L}$ pada ayam broiler yang tercekam panas akut dengan suhu $40^{\circ} \mathrm{C}$ dan kelembapan 40\% selama dua jam (Bogin et al. 1996).

Produksi triiodotironin menurun pada kondisi suhu yang tinggi, atau konsentrasinya meningkat pada saat suhu rendah (Melesse et al. 2011). Sebaliknya, produksi hormon kortikosteron pada korteks adrenal yang meningkat pada saat cekaman panas (Soleimani et al. 2011). Konsentrasi triiodotironin yang berbanding terbalik dengan konsentrasi kortikosteron juga ditemukan pada ayam broiler yang mengalami cekaman panas (Giloh et al. 2012).

Termoregulasi merupakan hasil kerja dari beberapa organ tubuh yang saling berhubungan. Organ penting dalam proses pengaturan suhu tubuh adalah hipotalamus. Hipotalamus ini berfungsi untuk mengatur kerja beberapa hormon yang berpengaruh pada cekaman panas, di antaranya ialah hormon adenokortikotropik, triiodotironin, dan kortikosteron. Produksi hormon adenokortikotropik pada kelenjar pituitari di otak akan meningkat pada saat cekaman panas dan hal ini akan menurunkan metabolisme tubuh secara umum. Melalui mekanisme termoregulasi, hipotalamus akan menghambat pembentukan thyroid releasing hormone (TRH) dan thyroid stimulating hormone (TSH) pada kelenjar tiroid sehingga hormon tiroksin berupa triiodotironin (T3) dan tetraiodotironin (T4) tidak banyak diproduksi. Akibatnya ialah metabolisme tubuh menurun dan selanjutnya berdampak pada penurunan produksi panas. Hormon T3 bersifat aktif dan bebas beredar di dalam aliran darah $(0,5 \%)$. Umumnya tiroksin berperan dalam pertumbuhan sementara kortikosteron dihasilkan oleh kelenjar adrenal. Hormon kortikosteron ini berperan dalam proses glikolisis dan dalam mempertahankan kadar glukosa darah.

Secara singkat penelitian ini mengungkap bahwa respons fisiologis (waktu mulai panting, suhu rektal, suhu permukaan tubuh, dan konsentrasi hormon) ayam KUB sama untuk semua haplotipe $\left(\mathrm{H} 1{ }^{\prime}, \mathrm{H} 1, \mathrm{H} 2\right.$, dan $\mathrm{H} 3$ ); sedangkan respons fisiologis ayam walik berbeda signifikan pada haplotipe $\mathrm{H} 1$ untuk suhu rektal dan $\mathrm{H}_{1}$ ' untuk suhu permukaan di area kaki. Peningkatan suhu rektal tertinggi pada ayam walik haplotipe $\mathrm{H} 1$ mengindikasikan bahwa ayam ini tidak tahan terhadap cekaman panas. Di sisi lain, tingginya peningkatan suhu permukaan di area kaki ayam walik haplotipe $\mathrm{H} 1$ ' mengisyaratkan bahwa panas yang dilepaskan di area kaki lebih banyak dibandingkan dengan di area lainnya.

\section{KESIMPULAN}

Ayam walik haplotipe $\mathrm{H} 1$ lebih rentan terhadap cekaman panas berdasarkan pengukuran suhu rektal, sementara ayam walik haplotipe $\mathrm{H} 1$ ' lebih banyak melepaskan panas melalui permukaan tubuh di area kaki.

\section{UCAPAN TERIMA KASIH}

Penulis mengucapkan terima kasih kepada Direktorat Jenderal Pendidikan Tinggi Kementerian Pendidikan dan Kebudayaan atas Beasiswa Pendidikan Pascasarjana Dalam Negeri (BPPDN) tahun anggaran 2014.

\section{DAFTAR PUSTAKA}

Ajakaiye JJ, Pérez AB, Mollineda AT. 2011. Effects of high temperature on production in layer chickens supplemented with vitamins $\mathrm{C}$ and $\mathrm{E}$. Revista MVZ Córdoba. 16(1): 2283-2291.

Archana PR, Aleena I, Pragua P, Vidya MK, Niyas APA, Bagath M, Krishnan G, Manimaran A, Beena V, Kurien EK, Sejian V, Bhatta R. 2017. Role of heat shock proteins in livestock adaptation to heat stress. Journal of Dairy, Veterinary and Animal Research. 5(1): 00127.

Aryani A, Solihin DD, Sumantri C, Afnan R, Sartika T. 2019. Genetic diversity of the structure of HSP70 gene in kampung unggul Balitbangtan (KUB), walik and kate walik chickens. Tropical Animal Science Journal. 42(3):1 80-188. https://doi.org/10.5398/ tasj.2019.42.3.180.

Barrett NW, Rowland K, Schmidt CJ, Lamont SJ, Rothschild MF, Ashwell CM, Persia ME. 2019. Effects of acute and chronic heat stress on the performance, egg quality, body temperature, and blood gas parameters of laying hens. Poultry Science. 98: 6684-6692. https://dx.doi.org/ 10.3382/ps/pez541.

Bogin E, Avidar Y, Pech-Waffenschmidt, Doron Y, Israeli BA, Kevkhayev E. 1996. The relationship between heat stress, survivability and blood composition of the domestic chicken. European Journal of Clinical Chemistry and Clinical Biochemistry. 34(6): 463-469. https://doi.10.1515/ cclm.1996.34.6.463.

Chen XY, Wei PP, Xu SH, Geng ZY, Jiang RS. 2013. Rectal temperature as an indicator for heat 
tolerance in chicken. Animal Science Journal. 84: 737-739. https://doi.10.1111/asj.12064.

Cunningham JG, Klein BG. 2007. Textbook of Veterinary Physiology. 4th Ed. St. Louis Missouri (US): WB Saunders Elsevier.

Gerken M, Afnan R, Dörl J. 2006. Adaptive behavior in chickens in relation to thermoregulation. Archiv fur Geflügelkunde. 70(5): 199-207.

Giloh M, Shinder D, Yahav S. 2012. Skin surface temperature of broiler chickens is correlated to body core temperature and is indicative of their thermoregulatory status. Poultry Science. 91: 175-188. https://doi.10.3382/ps.2011-01497.

Kataria N, Kataria AK, Gahlot AK. 2008. Ambient temperature associated variations in serum hormones and interrelated analytes of broiler chickens in arid tract. Slovenian Veterinary Research. 45(4): 127-134.

Komalasari L. 2014. Dampak suhu tinggi terhadap respons fisiologi, profil darah dan performa produksi dua bangsa ayam berbeda [tesis]. Bogor (ID): Institut Pertanian Bogor.

Lamoreux WF, Hutt FB. 1939. Variability of body temperature in the normal chick. Poultry Science. 18: $70-75$.

Liang HM, Lin DY, Hsuuw YD, Huang TP, Chang HL, Lin CY, Wu HH, Hung KH. 2016. Association of heat shock protein 70 gene polymorphisms with acute thermal tolerance, growth, and egg production traits of native chickens in Taiwan. Archives Animal Breeding. 59: 173-181. http://doi.org/10.5194/aab59-173-2016.

Lin H, Jiao HC, Buyse J, Decuypere E. 2006. Strategies for preventing heat stress in poultry. World's Poultry Science Journal. 62(1): 71-86. http://doi.org/10.1079/WPS200585.

Mazzi CM, Ferro JA, Ferro MIT, Savino VJM, Coelho AAD, Macari M. 2003. Polymorphism analysis of the hsp70 stress gene in broiler chickens (Gallus gallus) of different breeds. Genetics and Molecular Biology. 26(3): 275-281. https://doi.org/10.1590/S141547572003000300010.

McCafferty DJ. 2013. Applications of thermal imaging in avian science. The International Journal of Avian Science. 155: 4-15.

Melesse A, Maak S, Schmidt R, Lengerken GV. 2011. Effect of long-term heat stress on key enzyme activities and T3 levels in commercial layer hens.
International Journal of Livestock Production. 2(7): 107-116.

Nääs IA, Romanini CEB, Neves DP, Nascimento GR, Vercellino RA. 2010. Broiler surface temperature distribution of 42 day old chickens. Scientia Agricola. 67(5): 497-502.

Nascimento GR, Nääs IA, Pereira DF, Baracho MS, Garcia R. 2011. Assessment of broiler surface temperature variation when exposed to different air temperatures. Brazilian Journal of Poultry Science. 13(4): 259-263.

Osti R, Bhattarai D, Zhou D. 2017. Climatic variation: effects on stress level, feed intake, and body weight of broilers. Brazilian Journal of Poultry Science. 19(3): 489-496. http://dx.doi.org/10.1590/18069061-2017-0494.

Romanoff AL. 1941. Development of homeothermy in birds. Science. 94(2435):218-219. http://doi.org/ 10.1126/science.94.2435.218.

Soleimani AF, Zulkifli I, Omar AR, Raha AR. 2011. Physiological responses of 3 chicken breeds to acute heat stress. Poultry Science. 90: 1435-1440.

Sugito, Delima M. 2009. Dampak cekaman panas terhadap pertambahan bobot badan, rasio heterofil:limfosit dan suhu tubuh ayam broiler. Jurnal Kedokteran Hewan. 3(1): 218-226.

Tamzil MH, Noor RR, Hardjosworo PS, Manalu W, Sumantri C. 2013a. Keragaman gen heat shock protein 70 pada ayam kampung, ayam arab dan ayam ras. Journal of Veterinary. 14(3): 317-326.

Tamzil MH, Noor RR, Hardjosworo PS, Manalu W, Sumantri C. 2013b. Acute heat stress responses of three lines of chickens with different heat shock protein (HSP)-70 genotypes. International Journal of Poultry Science. 12(5): 264-272.

Tkáčová J, Angelovičová M. 2012. Heat shock protein (HSPs): a review. Journal of Animal Science and Biotechnology. 45(1): 349-353.

Wilson, WO. 1948. Some effects of increasing environmental temperatures on pullets. Poultry Science. 27: 813-817.

Yalçin S, Testik A, Ozkan S, Settar P, Çelen F, Cahaner A. 1997. Performance of naked neck and normal broilers in hot, warm, and temperate climates. Poultry Science. 76(7): 930-937. http://doi.org/10.1093/ps/76.7.930.

Zhao Y, Xin H, Dong B. 2013. Use of infrared thermography to assess laying-hen feather coverage. Poultry Science. 92: 295-302. 